University of New Orleans

ScholarWorks@UNO

$11-2010$

\title{
Effects of Hurricane Katrina on freshwater fish assemblages in a small coastal tributary of Lake Pontchartrain, Louisiana
}

Martin O'Connell

University of New Orleans, moconnel@uno.edu

Follow this and additional works at: https://scholarworks.uno.edu/ees_facpubs

Part of the Environmental Sciences Commons

\section{Recommended Citation}

Van Vrancken, J. and M.T. O'Connell. 2010. Effects of Hurricane Katrina on freshwater fish assemblages in a small coastal tributary of Lake Pontchartrain, Louisiana. Transactions of the American Fisheries Society 139: 1723-1732.

This Article is brought to you for free and open access by the Department of Earth and Environmental Sciences at ScholarWorks@UNO. It has been accepted for inclusion in Earth and Environmental Sciences Faculty Publications by an authorized administrator of ScholarWorks@UNO. For more information, please contact scholarworks@uno.edu. 
This article was downloaded by: [University of New Orleans]

On: 4 May 2011

Access details: Access Details: [subscription number 933133281]

Publisher Taylor \& Francis

Informa Ltd Registered in England and Wales Registered Number: 1072954 Registered office: Mortimer House, 3741 Mortimer Street, London W1T 3JH, UK

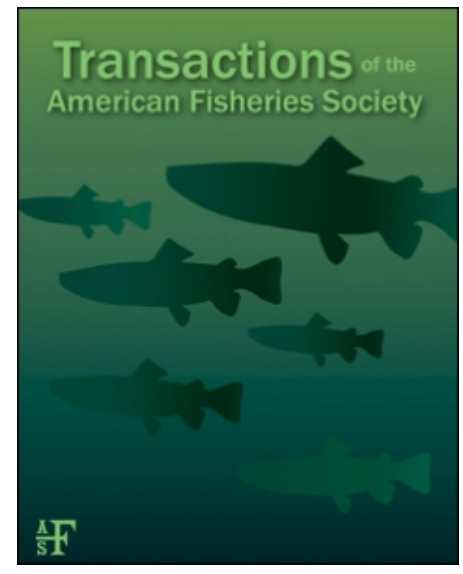

\section{Transactions of the American Fisheries Society}

Publication details, including instructions for authors and subscription information:

http://www.informaworld.com/smpp/title content=t927035360

\section{Effects of Hurricane Katrina on Freshwater Fish Assemblages in a Small Coastal Tributary of Lake Pontchartrain, Louisiana}

Jeffrey van Vrancken ${ }^{\mathrm{a}}$; Martin O'Connell ${ }^{\mathrm{b}}$

${ }^{\text {a }}$ U.S. Fish and Wildlife Service, Niceville, Florida, USA b Pontchartrain Institute for Environmental Sciences, University of New Orleans, New Orleans, Louisiana, USA

First published on: 15 February 2011

To cite this Article van Vrancken, Jeffrey and O'Connell, Martin(2010) 'Effects of Hurricane Katrina on Freshwater Fish Assemblages in a Small Coastal Tributary of Lake Pontchartrain, Louisiana', Transactions of the American Fisheries Society, 139: 6, 1723 - 1732, First published on: 15 February 2011 (iFirst)

To link to this Article: DOI: $10.1577 /$ T09-217.1

URL: http://dx.doi.org/10.1577/T09-217.1

\section{PLEASE SCROLL DOWN FOR ARTICLE}

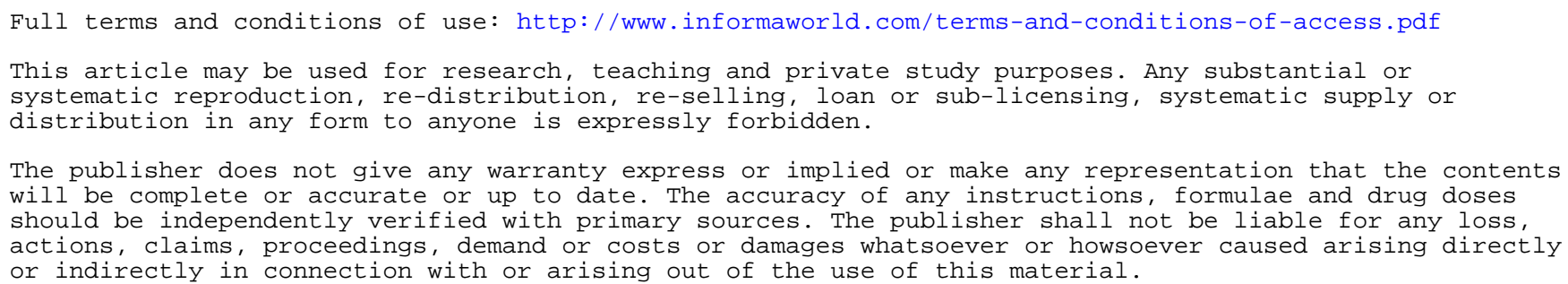




\title{
Effects of Hurricane Katrina on Freshwater Fish Assemblages in a Small Coastal Tributary of Lake Pontchartrain, Louisiana
}

\author{
JEFFREY VAN VRANCKEN* \\ U.S. Fish and Wildlife Service, Jackson Guard, Eglin Air Force Base, 107 Highway 85 North, \\ Niceville, Florida 32578, USA
}

Martin O'Connell

Pontchartrain Institute for Environmental Sciences, University of New Orleans, 2000 Lakeshore Drive, New Orleans, Louisiana 70148, USA

\begin{abstract}
Hurricane Katrina struck southeastern Louisiana on 29 August 2005 and thereby created an opportunity to examine the effects of a catastrophic storm on fish assemblages in a coastal stream. Bayou Lacombe is a small (46.1 river kilometers), primarily freshwater stream that drains into the northeastern portion of Lake Pontchartrain, a large oligohaline estuary located north of New Orleans. In summer 2005 (prior to the hurricane), three upstream and three downstream reaches of Bayou Lacombe were surveyed by electrofishing. These same six reaches were resurveyed in the summer of 2006 to assess the effects of the hurricane on fish assemblages. There were significant changes in fish assemblages at the downstream and upstream reaches. At the downstream reaches, centrarchid species such as bluegill Lepomis macrochirus, warmouth $L$. gulosus, and redspotted sunfish L. miniatus increased in abundance after the hurricane, as did inland silverside Menidia beryllina and striped mullet Mugil cephalus, both estuarine-dependent species. At the upstream reaches, longear sunfish L. megalotis decreased after the hurricane and weed shiners Notropis texanus, goldstriped darters Etheostoma parvipinne, and warmouth were absent from posthurricane samples. Principal components and BEST analyses showed that differences in dissolved oxygen between years were related to fish assemblage changes in the upstream reaches. Salinity and temperature were associated with fish assemblage changes in the downstream reaches. Similar significant changes could occur in other coastal streams prone to increased hurricane activity.
\end{abstract}

Natural disturbances such as droughts, floods, and violent storms have the potential to alter fish assemblage structure. Large infrequent disturbances are thought to play as large a role in shaping a fish assemblage's composition, as do biological interactions such as competition and predation, which generally receive much more attention (Sousa 1984; Resh et al. 1988; Poff and Ward 1989). Natural disturbances can serve as an ecological reset mechanism by causing local disequilibrium (Sousa 1984). More numerous species stand a better chance of losing a larger proportion of their population from a disturbance. This can provide opportunities for more rare species to compete with once predominant species after the environmental conditions have changed. A primary focus of aquatic ecology is to understand how severe environmental changes can alter fish assemblages (Matthews 1998), although there are few studies connecting major disturbances with significant changes in the composition of freshwater fish assemblages (Tillman 1989; Dolloff et al. 1994; Collins 2000).

\footnotetext{
* Corresponding author: jeffrey_vanvrancken@fws.gov
}

Received November 11, 2009; accepted June 19, 2010 Published online November 10, 2010
In coastal regions of the southeastern United States, hurricanes can inflict multiple violent disturbances on local aquatic communities. Heavy rainfall, storm surge inundation, and extreme winds are the primary forces that cause damage to coastal species and habitats. During a slow-moving storm, large amounts of rainfall can cause severe runoff pollution problems. For example, in 1996 when Hurricane Fran made landfall in North Carolina, local rivers experienced extensive fish kills caused by runoff pollutants (Mallin et al. 1999). Saltwater storm surges can create devastating turbulence that not only causes direct fish mortality but also disturbs anoxic sediments that can create shortterm anoxic or hypoxic conditions in estuaries and intertidal zones (Mallin et al. 1999; Buck 2005). Hurricane winds can also uproot trees and produce 1.22.0 times the annual mean litterfall by defoliation, as was observed at an experimental forest in Puerto Rico after Hurricane Hugo struck in 1989 (Lodge and McDowell 1991). Increased amounts of leaf litter in aquatic systems can cause marked increases in nutrient inputs to these systems (Lodge et al. 1991; Schaefer et al. 2000; Mallin et al. 2002), which in turn, can lead to bottom water hypoxia (Paerl et al. 2001). Because of the lack of preimpact data available, there have been 
few attempts to directly measure how these hurricane impacts affect fish assemblages (Paperno et al. 2006; Stevens et al. 2006).

On 29 August 2005, Hurricane Katrina made landfall on Gulf Coast of Mississippi and southeastern Louisiana. The western part of the eye, with winds in excess of $240 \mathrm{~km} / \mathrm{h}$ passed directly over Bayou Lacombe, Louisiana. Prior to the storm, we were conducting an ongoing survey of Bayou Lacombe with the goal of assessing long-term fish assemblage changes. The hurricane, although catastrophic to the human populations of southeastern Louisiana and the Mississippi Gulf Coast, presented a unique opportunity to conduct a natural experiment to study the storm's effects on fish assemblages. The saltwater storm surge penetrated much of the lower portions of Bayou Lacombe and caused the stream to overflow into surrounding areas, inundating natural floodplains. Due to extensive wave action, the storm surge also damaged healthy marshes downstream. Hurricane winds felled large pine trees into the headwater portions of the stream, damaging or destroying riparian vegetation. Our goal was to determine whether fish assemblages in upstream and downstream reaches of Bayou Lacombe were resilient (i.e., did not change significantly after exposure to a stressor) to either storm surge inundation or the destruction of riparian vegetation. We also hoped to determine which environmental impacts most affected the local fishes. In order to measure fish assemblage composition and possible changes in environmental conditions, we surveyed six reaches of Bayou Lacombe prior to Hurricane Katrina during summer 2005 and resurveyed the same reaches in summer 2006.

\section{Study Location}

Bayou Lacombe is a small (46.1 river kilometers), low-gradient stream in St. Tammany Parish terminating in Lake Pontchartrain (Figure 1). From our preliminary analysis of historical data, the Bayou can be divided into two different ecosystems. The upstream habitats of the Bayou contain mostly freshwater species typical of a Gulf coastal plain stream (e.g., Cyprinidae, Centrarchidae, and Percidae). The shallow (typically $<1$ $\mathrm{m})$ habitats have clear, tannin-stained water that flows slowly through riffles, runs, and pools. The substrate is sandy with very little aquatic vegetation other than occasional sunken logs. All upstream reaches we surveyed were chosen based on historical sampling sites near road crossings. The downstream habitats of the Bayou are wider and deeper with increased turbidity. Water flow is more sluggish, especially in those habitats occurring within the intertidal zone, which is partially influenced by the oligohaline waters of Lake Pontchartrain. Downstream sampling occurred in this zone where the Bayou's shallow stream characteristics become more sluggish with deeperwater habitats. The habitat here consists mainly of cypress trees Taxodium distichum, aquatic vegetation (e.g., coontail Ceratophylum demersum), and woody debris. Reaches farther south of reach 6 were eliminated shortly after starting the project due to difficulty of using electrofishing near the saline waters of Lake Pontchartrain.

\section{Methods}

All reaches were sampled by either backpack or boat electrofishing. Although electrofishing targets certain fish species more effectively than others (i.e., larger fish provide a greater voltage gradient for electrical current than smaller species), it proved to be the best method of sampling for post-Katrina sampling because Bayou Lacombe was littered with fallen trees following the storm. The presence of debris precluded effective sampling by seining. All efforts were made to ensure that sampling effort and methods remained constant between 2005 and 2006 surveys. For both electrofishing approaches, specimens of large species were identified in the field and released. Smaller individuals were either stored on ice or fixed in $10 \%$ buffered formalin and returned to the laboratory for processing. Processing the samples included identifying each specimen to species, counting the number of specimens per species, recording the total bulk weight of each species, and measuring the standard length (SL) of the individual.

The three upper reaches of Bayou Lacombe (reaches 1-3) were electrofished using a Smith-Root backpack DC electrofisher (Model 12-A POW). Electrofishing at each reach consisted of three 15-min sampling periods (total $45 \mathrm{~min}$ ) during which all habitats, including riffles, runs, and pools were sampled (or a total of nine upstream sites). One person dipped fish while the second operated the electrofisher. For each $15 \mathrm{~min}$ sampling period, a random start location was determined prior to sampling. To allow for direct comparisons, the same reaches samples in 2005 were resampled in 2006. All collections were made during June, July, and August of each year. We measured water temperature, salinity, specific conductance, percent saturation of oxygen, and dissolved oxygen prior to each sampling period using a Yellow Springs Instruments model $85 \mathrm{~m}$.

Fish at the three downstream sampling reaches (reaches 4-6) were collected with a Coeffelt model DC electrofisher operated from a boat (one driver, two dippers). In an effort to hold fishing effort constant, a 200-m reach, established via a Global Positioning 


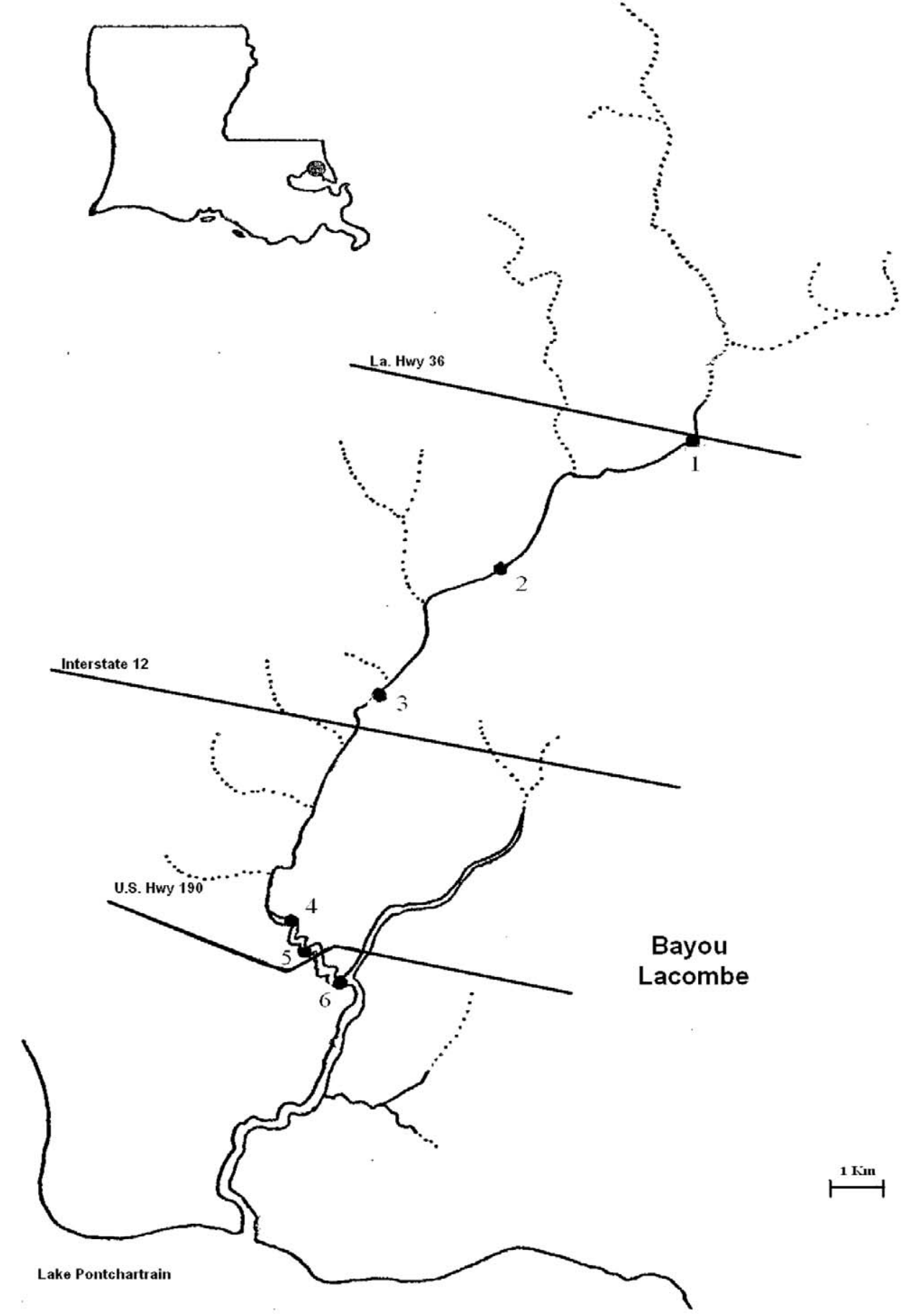

FIGURE 1.-Map of Bayou Lacombe showing the upstream (1-3) and downstream (4-6) reaches where the fish population was examined before (2005) and after (2006) Hurricane Katrina. Sampling stations were modified from Farabee (1992). 
System unit, was electrofished using a single-pass technique. All structures within the reach (fallen trees, fishing docks, etc.) were targeted for sampling. When sampling around these structures, the distance around each was calculated and added to the total distance sampled. After a reach had been sampled, electrofishing was continued on the opposite side of the channel with a similar approach. An individual sample consisted of three electrofishing passes: one along each of two banks and a single pass through the midchannel. Total distances electrofished were recorded and averaged about $800-1,000 \mathrm{~m}$ per sample. For each sample, we measured the same water quality variables as in the upstream reaches.

We compared fish assemblages collected from all sites during summer 2005 (pre-Katrina) and summer 2006 (post-Katrina) by using assemblage analysis procedures in the PRIMER (Plymouth Routines in Multivariate Ecological Research) version 6 statistical package (Clarke and Warwick 2001; Clarke and Gorley 2006). Water quality variables in 2005 versus 2006 were also compared to determine if water quality changed over that period. To test for significant differences among assemblages and between years, upstream and downstream fish assemblage data (numbers of individuals per species) were compared using analysis of similarity (ANOSIM) at $\alpha=0.05$. For these analyses, no species were excluded due to rarity. We also constructed nonmetric multidimensional scaling (MDS) plots to show the relationships among the assemblages. Similarity matrices were generated for fish assemblages by square-root-transforming the raw abundance data and calculating Bray-Curtis similarity indices for each pairwise assemblage comparison (Bray and Curtis 1957). We then calculated similarity percentages (SIMPER) using raw abundance data to determine which species were contributing most to any observed changes in assemblage composition (Clarke and Warwick 2001).

We also used PRIMER to test for differences in water quality data. Draftsman plots were constructed to identify those water quality variables that were highly collinear, such that these could be removed from the analyses. Based on this analysis, we assessed the remaining variables: water temperature, salinity, and dissolved oxygen. Data were then square-root-transformed, normalized, and a Euclidean distance matrix was produced before conducting an ANOSIM. Principle components analysis (PCA) and the BEST (BioEnv + STepwise) routine (Clarke and Gorley 2006) were then conducted to assess differences in water quality factors between the respective groups of samples. By using the BEST routine and PCA simultaneously, one can observe how well the abiotic variables explain the biotic variables.

\section{Results \\ Upstream Reaches}

We collected 1,380 fish comprising 26 species, 18 genera, and 10 families in the upstream reaches; 666 fish were collected in summer 2005 and 714 in summer 2006. Fish assemblages in 2005 were significantly different than those in 2006 (ANOSIM: $R=0.836, P=$ $0.001)$ with MDS plots of fish assemblage centroids exhibiting no overlap in the ordination between years (Figure 2). In 2006, the largest decline of any species (Table 1) was noted in longear sunfish. Abundances of blackspotted topminnow, redfin pickerel, bluegills, and redspotted sunfish all showed lesser decreases between pre-Katrina and post-Katrina collections. Three species caught consistently in low number in each of the nine 2005 collections (warmouths, goldstripe shiners, and weed shiners) were not captured in any of the summer 2006 samples. Species caught consistently in low numbers in 2005 (pirate perch, banded pygmy sunfish, and western mosquitofish) exhibited marked increases in 2006. This also occurred with largemouth bass, although 2006 fish were smaller than 2005 fish (average standard length $=64$ versus $96 \mathrm{~mm}$ ). In addition, sharpfin suckers and yellow bullheads showed slight increases in abundance in 2006.

\section{Downstream Reaches}

We collected a total of 1,404 fish comprising 34 species, 23 genera, and 13 families in the downstream reaches; 379 fish were collected in summer 2005 and 1,025 in summer 2006. Fish assemblages in 2005 were significantly different than those in 2006 MDS plots of fish assemblage centroids exhibiting some overlap in the ordination between years (ANOSIM: $R=0.473, P$ $=0.003$; Figure 3). All centrarchid species showed increases in abundance between 2005 and 2006 (Table 2 ). While some increases were small (bluegills, warmouths, and redspotted sunfish), others were large (largemouth bass and redear sunfish). Small increases were also found for other ambush predators (i.e., besides largemouth bass), such as spotted gar and bowfin. Two estuarine-dependent species (inland silverside and striped mullet) were more abundant in 2006, while two other estuarine-dependent species (Gulf menhaden and bay anchovy) were collected in summer 2006 but not in 2005 .

\section{Water Quality}

There were significant differences between 2005 and 2006 in water quality at upstream reaches (ANOSIM: $R$ $=0.370, P=0.007)$, primarily because of a large 


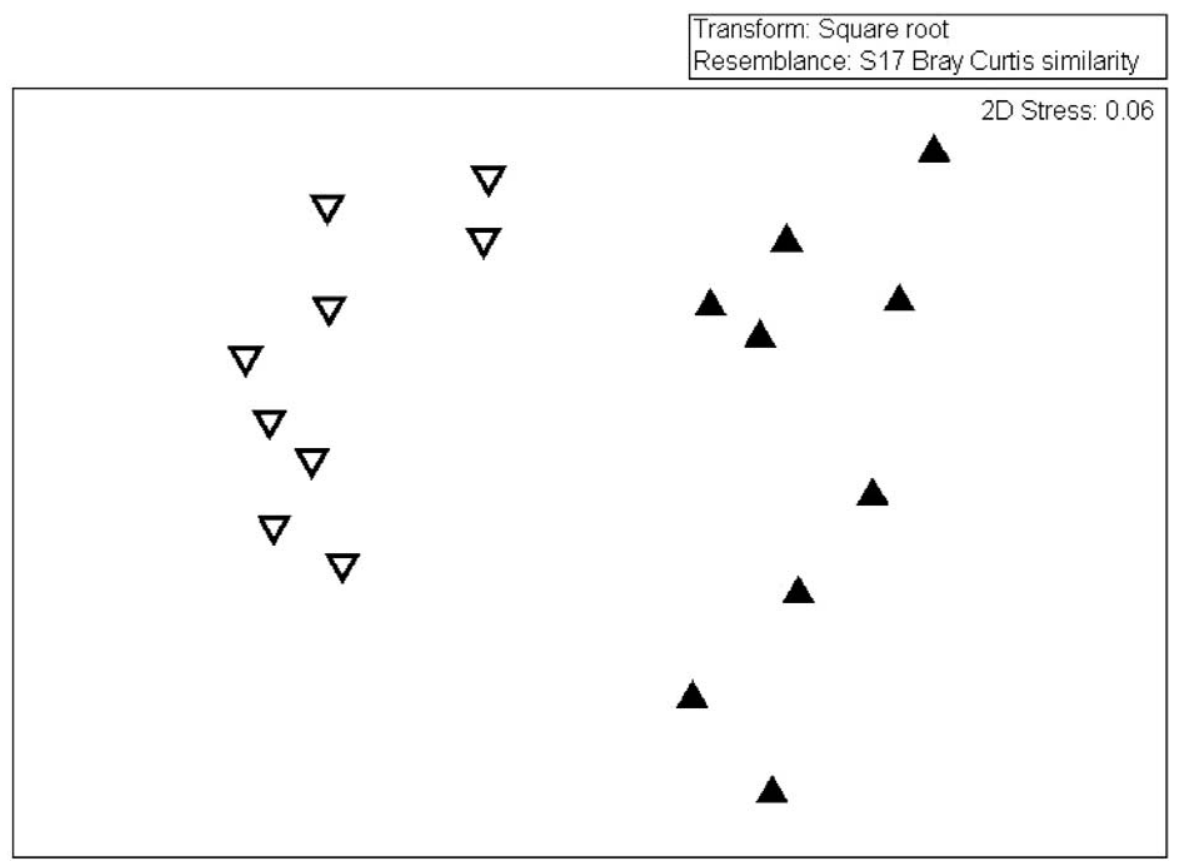

FIGURE 2.-Nonmetric multidimensional scaling plot comparing upstream fish assemblage samples collected in summer 2005 (solid triangles) with those collected in summer 2006 (open triangles).

decrease in dissolved oxygen in 2006 (Figure 4). There were also significant between-year changes in water quality at the downstream reaches (ANOSIM: $R=$ $0.531, P=0.001$ ). Dissolved oxygen levels remained relatively constant between years at downstream reaches, though we did observe increases in both temperature and salinity in downstream samples in 2006. A simultaneous assessment of both fish assemblages and environmental data using PCA and BEST supported the conclusion of the ANOSIM and allowed visual interpretation of the relationships.

\section{Discussion}

Upstream fish assemblages in Bayou Lacombe changed significantly after Hurricane Katrina, and these alterations to the species composition were identifiable the summer after the storm in 2006. While the storm surge itself did not extend into these reaches,

TABLE 1.-Analysis of similarity $(R=0.836, P=0.001)$ and similarity percentages for fish collected at the upstream stations in Bayou Lacombe between summer 2005 and 2006 sampling periods. Cutoff for low contributions was 90\%; Diss = dissimilarity.

\begin{tabular}{|c|c|c|c|c|c|c|}
\hline \multirow[b]{2}{*}{ Species } & \multicolumn{2}{|c|}{ Average abundance } & \multirow[b]{2}{*}{ Average Diss } & \multirow[b]{2}{*}{ Diss/SD } & \multicolumn{2}{|c|}{ Percent contribution } \\
\hline & 2005 & 2006 & & & By species & Cumulative \\
\hline Longear sunfish Lepomis megalotis & 5.55 & 2.14 & 7.87 & 1.82 & 12.74 & 12.74 \\
\hline Banded pygmy sunfish Elassoma zonatum & 0.33 & 3.31 & 6.58 & 2.4 & 10.66 & 23.4 \\
\hline Pirate perch Aphredoderus sayanus & 1.79 & 4.85 & 6.58 & 2.4 & 10.65 & 34.05 \\
\hline Largemouth bass Micropterus salmoides & 0.6 & 3.26 & 5.84 & 2.33 & 9.46 & 43.51 \\
\hline Redfin pickerel Esox americanus & 2.6 & 1.61 & 3.62 & 1.08 & 5.87 & 49.38 \\
\hline Blackspotted topminnow Fundulus olivaceus & 1.63 & 0.71 & 3.55 & 1.06 & 5.75 & 55.13 \\
\hline Warmouth Lepomis gulosus & 1.59 & 0 & 3.45 & 4.08 & 5.59 & 60.72 \\
\hline Bluegill Lepomis macrochirus & 2.71 & 2.05 & 3.45 & 1.36 & 5.58 & 66.31 \\
\hline Western mosquitofish Gambusia affinis & 0.11 & 1.61 & 3.34 & 1.24 & 5.41 & 71.71 \\
\hline Yellow bullhead Ameiurus natalis & 0.41 & 1.61 & 2.89 & 1.41 & 4.68 & 76.39 \\
\hline Sharpfin chubsucker Erimyzon tenuis & 0.54 & 1.12 & 2.67 & 0.98 & 4.32 & 80.71 \\
\hline Goldstripe darter Etheostoma parvipinne & 1.01 & 0 & 2.27 & 0.94 & 3.67 & 84.38 \\
\hline Redspotted sunfish Lepomis miniatus & 0.79 & 0.43 & 1.91 & 1.24 & 3.09 & 87.47 \\
\hline Weed shiner Notropis texanus & 0.54 & 0 & 1.12 & 0.68 & 1.82 & 89.29 \\
\hline Bayou topminnow Fundulus notti & 0.44 & 0.22 & 1.12 & 0.79 & 1.81 & 91.1 \\
\hline
\end{tabular}




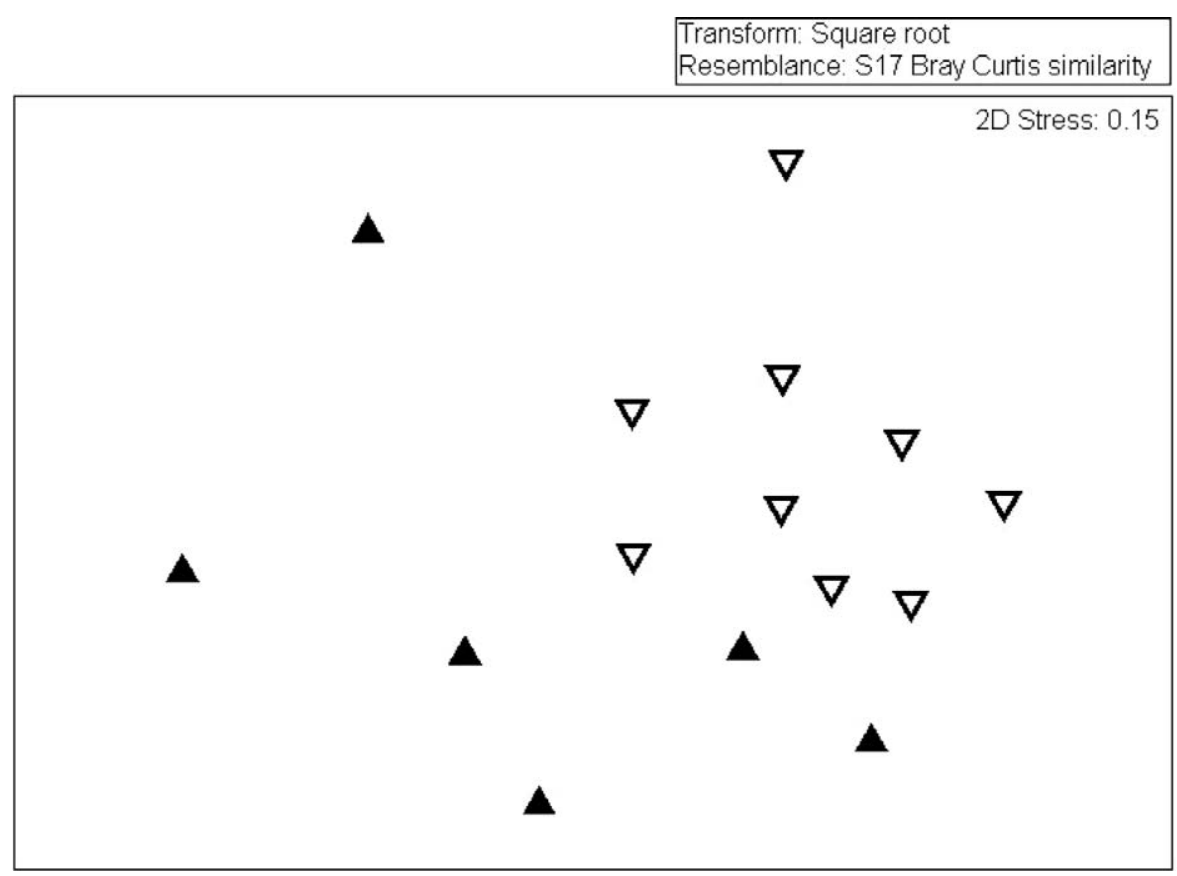

FIGURE 3.- Nonmetric multidimensional scaling plot comparing downstream fish assemblage samples collected in summer 2005 (solid triangles) with those collected in summer 2006 (open triangles).

the habitats were impacted by other hurricane-related changes. Although instream habitat was not quantified at upstream reaches, we observed a marked increase in stream habitat complexity following the hurricane. Uprooted trees and large amounts of riparian defoliation combined to create debris dams within Bayou Lacombe. These dams have been observed in other streams after hurricanes (Covich et al. 1991; Dolloff et al. 1994; Schaefer et al. 2006), and they concentrate leaf litter created by the storm. Detritivores thrive in these conditions (Waide 1991), and the increased microbial activity and respiration often leads to reduced dissolved oxygen (Hill et al. 1998), as we observed in the upstream reaches in 2006. In other systems,

TABLE 2.-Analysis of similarity $(R=0.473, P=0.003)$ and similarity percentages for fish collected at the downstream stations in Bayou Lacombe between summer 2005 and 2006 sampling periods. Cutoff for low contributions was 90\%; Diss = dissimilarity.

\begin{tabular}{|c|c|c|c|c|c|c|}
\hline \multirow[b]{2}{*}{ Species } & \multicolumn{2}{|c|}{ Average abundance } & \multirow{2}{*}{$\begin{array}{c}\text { Average } \\
\text { Diss }\end{array}$} & \multirow[b]{2}{*}{ Diss/SD } & \multicolumn{2}{|c|}{ Percent contribution } \\
\hline & 2005 & 2006 & & & By species & Cumulative \\
\hline Largemouth bass & 3 & 5.66 & 6.06 & 1.49 & 12.11 & 12.11 \\
\hline Bluegill & 5.24 & 5.42 & 5.76 & 1.46 & 11.51 & 23.62 \\
\hline Redear sunfish Lepomis microlophus & 0.47 & 2.67 & 4.95 & 1.85 & 9.89 & 33.51 \\
\hline Inland silverside Menidia beryllina & 0.4 & 1.49 & 3.3 & 0.83 & 6.6 & 40.1 \\
\hline Redspotted sunfish & 2.34 & 2.96 & 3.21 & 1.32 & 6.41 & 46.51 \\
\hline Striped mullet Mugil cephalus & 0.76 & 1.38 & 2.68 & 1.01 & 5.36 & 51.87 \\
\hline Warmouth & 1.14 & 1.6 & 2.62 & 1.23 & 5.24 & 57.12 \\
\hline Brook silverside Labidesthes sicculus & 1.19 & 0.11 & 2.6 & 1 & 5.2 & 62.32 \\
\hline Gulf menhaden Brevoortia patronus & 0 & 1.17 & 2.59 & 0.74 & 5.18 & 67.5 \\
\hline Hogchoker Trinectes maculatus & 0 & 1.13 & 2.58 & 1.63 & 5.15 & 72.65 \\
\hline American eel Anguilla rostrata & 0.5 & 0.99 & 1.89 & 1.16 & 3.77 & 76.42 \\
\hline Rainwater killifish Lucania parva & 0.41 & 0.44 & 1.62 & 0.85 & 3.23 & 79.65 \\
\hline Blue catfish Ictalurus furcatus & 0.17 & 0.53 & 1.24 & 0.89 & 2.48 & 82.14 \\
\hline Bay anchovy Anchoa mitchilli & 0 & 0.56 & 1.21 & 0.52 & 2.43 & 84.56 \\
\hline Yellow bullhead & 0.4 & 0.22 & 0.98 & 0.82 & 1.96 & 86.52 \\
\hline Spotted gar Lepisosteus oculatus & 0.17 & 0.38 & 0.96 & 0.77 & 1.92 & 88.44 \\
\hline Bowfin Amia calva & 0.17 & 0.27 & 0.83 & 0.67 & 1.66 & 90.1 \\
\hline
\end{tabular}




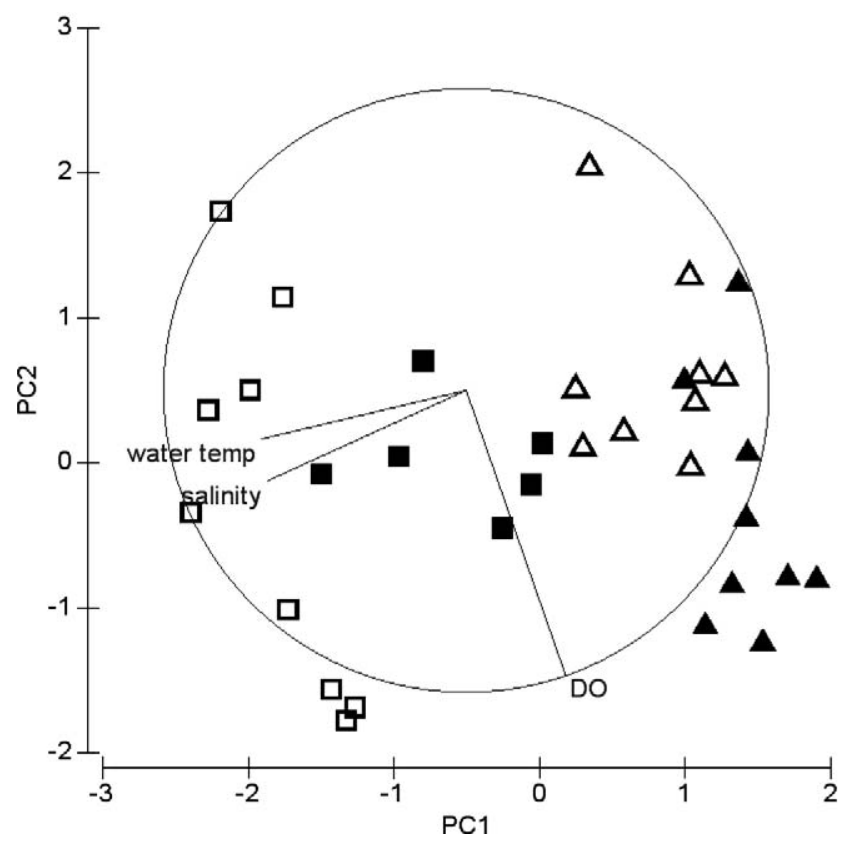

FIGURE 4.- Principal components analysis diagram showing upstream (triangles) and downstream (squares) fish assemblage samples collected during summer 2005 (solid symbols) and summer 2006 (open symbols) as they compare with water quality conditions.

localized algal blooms (Landsberg 2002) caused by increased nutrient inputs (Paerl 1988) and decreased riparian canopy (Tait et al. 1994) can also decrease dissolved oxygen. The creation of debris dams after Hurricane Katrina did not affect fish assemblages in a blackwater stream in coastal Mississippi (Schaefer et al. 2006) nor in small high-elevation streams in North Carolina after Hurricane Hugo (Dolloff et al. 1994). Our results differ from those in that we observed significant compositional changes in the upstream reaches, all Lepomis species decreasing. While various species of Lepomis are able to tolerate periods of low dissolved oxygen, they are unable to occupy habitats frequently or continuously experiencing low dissolved oxygen (Lewis 1970; Aday et al. 2000). Species that can tolerate low dissolved oxygen and occupy habitats with high concentrations of organic debris, such as pirate perch and banded pygmy sunfish (Pflieger 1975; Boschung and Mayden 2004), increased in these debris dam habitats. Bayou Lacombe probably experienced greater riparian damage and debris dam formation in its upstream reaches than either the Mississippi or North Carolina streams because it is closer to the coast where hurricanes are most violent.

The role of debris dams and low dissolved oxygen in shaping upstream fish assemblages was further em- phasized when sampling continued in fall 2006. By that time all instream habitat including debris dams and pre-Katrina habitat was mechanically removed to facilitate drainage. By spring 2007, dissolved oxygen levels returned to pre-Katrina levels, and the abundance of longear sunfish had markedly increased. This species was the most abundant upstream fish species prior to Hurricane Katrina, and it is known for its ability to reestablish in habitats after being displaced (Berra 1969; Gunning and Berra 1969; Berra and Gunning 1970). A similar longitudinal recovery was observed with stream biota exposed to low dissolved oxygen caused by sewage discharge (Hynes 1960). While the poststorm removal of debris helped restore water flow and decrease the build-up of decaying organic material, the impacts of mechanical clearing of bank vegetation were obvious and appear to be longlasting (VV, personal observation). In other streams, deforestation of riparian zones has caused bank destabilization and increased sedimentation while altering light and thermal regimes, all of which can impact fish assemblages (Schlosser 1991; Lenat and Crawford 1994; Jones et al. 1999).

Weed shiners were not collected following the storm and continue to be absent from ongoing sampling. This is particularly concerning because weed shiners were 
commonly collected during historical sampling in Bayou Lacombe (Sobczak 1976; Farabee 1992). In other streams, the availability of habitat refuges appeared to assist assemblage resilience in spite of major changes in habitat caused by storms (Dolloff et al. 1994). The likely extirpation of weed shiners may be due to the loss of refuge habitats during the storm. During this period, this cyprinid would have been trapped between decreased upstream dissolved oxygen and increased downstream salinity. Also, weed shiners are typically associated with submersed aquatic vegetation (Pflieger 1975; Boschung and Mayden 2004), which was uncommon in Bayou Lacombe even before the storm. We had collected weed shiners in a single patch of fanwort Cabomba sp. before Hurricane Katrina, and this vegetation did not survive the storm.

Unlike the upstream reaches, the downstream habitats appeared to have recovered completely by 2006, although salinity levels remained elevated from lingering storm water. Our analyses indicated a significant compositional change had occurred even though downstream fish assemblages in summer 2006 strongly resembled summer 2005 assemblages. The primary drivers of compositional change were the centrarchid species, which became more abundant after Hurricane Katrina. For example, the three predominant freshwater species in 2005 (bluegill, redspotted sunfish, and largemouth bass) were more abundant in 2006. These results differ from another study in Louisiana that showed that hurricanes Katrina and Rita negatively impacted sport fishes in the Atchafalaya River basin, including centrarchids (Perret et al. 2010). Unlike the lower reaches of Bayou Lacombe, the Atchafalaya habitats and the upstream reaches of Bayou Lacombe experienced tremendous physical changes that appear to have affected these species (Perret et al. 2010). Other drivers for compositional change were increases in the estuarine-dependent species inland silversides and striped mullet and two planktivorous estuarine-dependent species, bay anchovy and Gulf menhaden. These four species are commonly found in Lake Pontchartrain and likely entered Bayou Lacombe after the storm, following the increased salinity levels. All of the species collected from downstream reaches in the current study are known to tolerate temporary periods of brackish water (Peterson and Meador 1994) and can easily reside in salinities of 8 PSU or less (Keup and Bayless 1964). Only yellow bullheads and brook silversides Labidesthes sicculus, decreased in abundance in the downstream reaches following the perturbation. It is possible that the increased salinity was lethal or drove yellow bullheads to seek refuge upstream. As for the increase in inland silversides and decrease in brook silversides (both atherinopsids), there may have been some salinity-driven competition because they both exploit the same part of the water column and feeding niche (Boschung and Mayden 2004).

In upstream and downstream reaches of Bayou Lacombe, fish assemblages changed after the storm, the upstream reaches probably experiencing multiple extirpations of rarer species. More common and generalist species in both areas, however, exhibited rapid recovery and some species even increased in abundance. While initial mortality is high from storm surges, due to turbulence and low dissolved oxygen, estuarine fishes are mostly resilient to saltwater storm surges and recover to preimpact conditions within 4-6 weeks (Hutchinson and Williams 2003; Paperno et al. 2006; Stevens et al. 2006). Freshwater fishes in the downstream reaches (e.g., centrarchids) also exhibited an ability to withstand storm surge impacts. These species may have avoided direct mortality by moving further upstream and occupying interstitial places within typical instream habitats (e.g., among cypress knees, aquatic vegetation, sunken logs). These habitats can provide refuge and slow the effects of the incoming surge much like debris dams do in spring floods in other stream systems (Pearsons et al. 1992). In Bayou Lacombe, the greatest hurricane impacts on fish assemblages were associated with the physical destruction and alteration of habitats in the upstream reaches where certain species could not access refuge habitats. For managers wishing to maintain biodiversity in small coastal streams that are subject to hurricane impacts, a critical tactic should be to maximize available refuge habitats such as forested floodplains and in-stream structure. Without these, rarer freshwater species may face extirpation.

\section{Acknowledgments}

The authors would like to extend their gratitude to the editor and anonymous reviewers for their comments and suggestions in improving this manuscript. This research was partially funded by a grant from the National Oceanic and Atmospheric Administration (NA16FZ2719) as part of the Pontchartrain Restoration Act. We would like to thank the hard-working men and women of the Nekton Research Laboratory at the University of New Orleans for their dedication to conducting scientific research after such a devastating natural disaster as Hurricane Katrina. In particular, we would like to acknowledge C. S. Schieble for his help with fieldwork and electrofishing training. This manuscript represents publication 8 for the Nekton Research Laboratory, Pontchartrain Institute for Environmental Sciences. 


\section{References}

Aday, D. D., D. A. Rutherford, and W. E. Kelso. 2000. Field and laboratory determinations of hypoxic effects on RNA-DNA ratios of bluegill. American Midland Naturalist 143:433-442.

Berra, T. M. 1969. Repopulation of experimentally decimated sections of streams by longear sunfish, Lepomis megalotis megalotis (Rafinesque), and the significance of age structure, home range, and movements. Doctoral dissertation. Tulane University, New Orleans, Louisiana.

Berra, T. M., and G. E. Gunning. 1970. Repopulation of experimentally decimated sections of streams by longear sunfish, Lepomis megalotis megalotis (Rafinesque). Transactions of the American Fisheries Society 99:776781.

Boschung, H. T. Jr., and R. L. Mayden. 2004. Fishes of Alabama. Smithsonian Books, Washington, D.C.

Bray, J. R., and J. T. Curtis. 1957. An ordination of the upland forest communities of southern Wisconsin. Ecological Monographs 27:325-349.

Buck, E. H. 2005. Hurricanes Katrina and Rita: fishing and aquaculture industries-damage and recovery. Congressional Research Service, Report for Congress RS22241, Washington, D.C.

Clarke, K. R., and R. N. Gorley. 2006. PRIMER v6: user manual/tutorial. PRIMER-E, Plymouth, UK.

Clarke, K. R., and R. M. Warwick. 2001. Change in marine communities: an approach to statistical analysis and interpretation, 2nd edition. PRIMER-E, Plymouth, UK.

Collins, S. L. 2000. Disturbance frequency and community stability in native tallgrass prairie. American Naturalist 155:311-325.

Covich, A. P., T. A. Crowl, S. L. Johnson, D. Varza, and D. L. Certain. 1991. Post-Hurricane Hugo increases in atyid shrimp abundances in a Puerto Rican montane stream. Biotropica 23:448-454.

Dolloff, C. A., P. A. Flebbe, and M. D. Owen. 1994. Fish habitat and fish populations in a southern Appalachian watershed before and after Hurricane Hugo. Transactions of the American Fisheries Society 123:668-678.

Farabee, M. V. 1992. Diversity, distribution, and community stability of fishes in Bayou Lacombe. Master's thesis. University of New Orleans, New Orleans, Louisiana.

Gunning, G. E., and T. M. Berra. 1969. Fish repopulation of experimentally decimated segments in the headwaters of two streams. Transactions of the American Fisheries Society 98:305-308.

Hill, B. H., A. T. Herlihy, P. R. Kaufmann, and R. L. Sinsabaugh. 1998. Sediment microbial respiration in a synoptic survey of mid-Atlantic region streams. Freshwater Biology 39:493-501.

Hutchinson, N., and G. A. Williams. 2003. Disturbance and subsequent recovery of mid-shore assemblages on seasonal, tropical, rocky shores. Marine Ecology Progress Series 249:25-38.

Hynes, H. B. N. 1960. The biology of polluted waters. Liverpool University Press, Liverpool, UK.

Jones, E. B. III, G. S. Helfan, J. O. Harper, and P. V. Bolstad. 1999. Effects of riparian forest removal on fish assemblages in southern Appalachian streams. Conservation Biology 13:1454-1465.

Keup, L., and J. Bayless. 1964. Fish distribution at varying salinities in Neuse River basin, North Carolina. Chesapeake Science 5:119-123.

Landsberg, J. H. 2002. The effects of harmful algal blooms on aquatic organisms. Reviews in Fisheries Science 10:113390.

Lenat, D. R., and J. K. Crawford. 1994. Effects of land use on water quality and aquatic biota of three North Carolina piedmont streams. Hydrobiologia 294:185-199.

Lewis, W. M. Jr. 1970. Morphological adaptations of cyprinodontids for inhabiting oxygen deficient waters. Copeia 1970:319-326.

Lodge, D. J., and W. H. McDowell. 1991. Summary of ecosystem-level effects of hurricanes. Biotropica 23:373378.

Lodge, D. J., F. N. Scatena, C. E. Asbury, and M. J. Sanchez. 1991. Fine litterfall and related nutrient inputs resulting from Hurricane Hugo in subtropical wet and lower montane rain forests of Puerto Rico. Biotropica 23:336342 .

Mallin, M. A., M. H. Posey, M. R. McIver, D. C. Parsons, S. H. Ensign, and T. D. Alphin. 2002. Impacts and recovery from multiple hurricanes in a piedmont-coastal plain river system. BioScience 52:999-1010.

Mallin, M. A., M. H. Posey, G. C. Shank, M. R. McIver, S. H. Ensign, and T. D. Alphin. 1999. Hurricane effects on water quality and benthos in the Cape Fear watershed: natural and anthropogenic impacts. Ecological Applications 9:350-362.

Matthews, W. J. 1998. Patterns in freshwater fish ecology. Chapman and Hall, New York.

Paerl, H. W. 1988. Nuisance phytoplankton blooms in coastal, estuarine, and inland waters. Limnology and Oceanography 33:823-847.

Paerl, H. W., J. D. Bales, L. W. Ausley, C. P. Buzzell, L. B. Crowder, L. A. Eby, J. M. Fear, M. Go, B. L. Peierls, T. L. Richardson, and J. S. Ramus. 2001. Ecosystem impacts of three sequential hurricanes (Dennis, Floyd, and Irene) on the United States' largest lagoonal estuary, Pamlico Sound, NC. Proceedings of the National Academy of Sciences of the USA 98:5655-5660.

Paperno, R., D. M. Tremain, D. H. Adams, A. P. Sebastian, J. T. Sauer, and J. Dutka-Gianelli. 2006. The disruption and recovery of fish communities in the Indian River Lagoon, Florida, following two hurricanes in 2004. Estuaries and Coasts 29:1004-1010.

Pearsons, T. N., H. W. Li, and G. A. Lamberti. 1992. Influence of habitat complexity on resistance to flooding and resilience of stream fish assemblages. Transactions of the American Fisheries Society 121:427-436.

Perret, A. J., M. D. Kaller, W. E. Kelso, and D. A. Rutherford. 2010. Effects of Hurricanes Katrina and Rita on sport fish community abundance in the eastern Atchafalaya River basin, Louisiana. North American Journal of Fisheries Management 30:511-517.

Peterson, M. S., and M. R. Meador. 1994. Effects of salinity on freshwater fishes in the coastal plain drainages in the southeastern U.S. Reviews in Fisheries Science 2:95121.

Pflieger, W. L. 1975. The fishes of Missouri. Missouri Department of Conservation, Jefferson City.

Poff, N. L., and J. V. Ward. 1989. Implications of streamflow variability and predictability for lotic community struc- 
ture: a regional analysis of streamflow patterns. Canadian Journal of Fisheries and Aquatic Sciences 46:1805-1818.

Resh, V. H., A. V. Brown, A. P. Covich, M. E. Gurtz, H. W. Li, G. W. Munshall, S. R. Reice, A. L. Sheldon, J. B. Wallace, and R. Wissmar. 1988. The role of disturbance in stream ecology. Journal of the North American Benthological Society 7:433-455.

Schaefer, D. A., W. H. McDowell, F. N. Scatena, and C. E. Asbury. 2000. Effects of hurricane disturbance on stream water concentrations and fluxes in eight tropical forest watersheds of the Luquillo Experimental Forest, Puerto Rico. Journal of Tropical Ecology 16:189-207.

Schaefer, J., P. Mickle, J. Spaeth, B. R. Kreiser, S. B. Adams, W. Matamoros, P. Zuber, and P. Vigueira. 2006. Effects of Hurricane Katrina on the fish fauna of the Pascagoula River drainage. Pages 62-68 in Proceedings of the 36th annual Mississippi water resources conference. Mississippi Water Resources Institute, Jackson, and Mississippi State University, Mississippi State. Available: ichthyology.usm.edu/research/katrina_impact.pdf (October 2010).

Schlosser, I. J. 1991. Stream fish ecology: a landscape perspective. BioScience 41:704-712.
Sobczak, M. T. 1976. Physical and chemical factors affecting the distribution and occurrence of fishes in Bayou Lacombe, Louisiana. Doctoral dissertation. Tulane University, New Orleans, Louisiana.

Sousa, W. P. 1984. The role of disturbance in natural communities. Annual Review of Ecology and Systematics 15:353-391.

Stevens, P. W., D. A. Blewett, and J. P. Casey. 2006. Shortterm effects of a low dissolved oxygen event on estuarine fish assemblages following the passage of Hurricane Charley. Estuaries and Coasts 29:997-1003.

Tait, C. K., J. L. Li, G. A. Lamberti, T. N. Pearsons, and H. W. Li. 1994. Relationships between riparian cover and the community structure of high desert streams. Journal of the North American Benthological Society 13:45-56.

Tillman, D. 1989. Ecological experimentation: strengths and conceptual problems. Pages 136-157 in G. E. Likens, editor. Long-term studies in ecology: approaches and alternatives. Springer-Verlag, New York.

Waide, R. B. 1991. Summary of the response of animal populations to hurricanes in the Caribbean. Biotropica 23:508-512. 